\title{
A Coordenação Necessária
}

A

FEBRASGO cresceu muito ao longo de sua história assumindo novas funções. Este é o caminho natural e esperado de uma entidade associativa. É preciso evoluir constantemente para adaptar-se ao surgimento de novas realidades científicas, profissionais e sociais. De outra forma, a desatualização determina a estagnação e a instituição deixa de cumprir sua função. Hoje trabalhamos em diferentes frentes para o enaltecimento da Ginecologia e da Obstetrícia Brasileira e para o bem dos associados. Da atividade voltada exclusivamente para a promoção da atualização científica, pela publicação de periódicos (RBGO e Femina), jornais (Jornal da FEBRASGO) e dos protocolos de condutas, pela promoção de cursos e de congressos, além de manter e estimular o trabalho das Comissões Nacionais Especializadas e Estatutárias, elaborar e promover o Concurso para Obtenção do Título de Especialista em Ginecologia e Obstetrícia, a FEBRASGO engajou-se na melhoria da qualidade do especialista em formação, trabalhando e assessorando a Comissão Nacional de Residência Médica do Ministério de Educação e do Desporto, está junto a AMB lutando para a melhoria das tabelas que norteiam os pagamentos pelos nossos serviços, está participando dos trabalhos junto aos países do MERCOSUL para o estabelecimento de normas comuns que visem nortear o trabalho dos ginecologistas e obstetras, dessas nações, a partir do ano 2001.

À FEBRASGO, para que isto se torne realidade, necessita e conta com a colaboração inestimável de diversos colegas, sem os quais não seria possivel executar todas essas atividades. Somos uma grande equipe, muito grande, de tamanho continental. A função da Diretoria é coordenar este universo de frentes de trabalho, para que como um só corpo, todas as partes, estimuladas cresçam em harmonia e trabalhem em perfeita sintonia.

A Diretoria 